June 2019

\title{
Digital Commons and CONTENTdm: Not Entirely Accessible
}

Channon Arabit

San Jose State University, channontva@csu.fullerton.edu

Follow this and additional works at: https://scholarworks.sjsu.edu/ischoolsrj

Part of the Archival Science Commons, Cataloging and Metadata Commons, Collection Development and Management Commons, Information Literacy Commons, Museum Studies Commons, Scholarly Communication Commons, and the Scholarly Publishing Commons

Acknowledgements

I would like to thank the Student Research Journal, its editors, and Dr. Anthony Bernier for this opportunity.

\section{Recommended Citation}

Arabit, C. (2019). Digital Commons and CONTENTdm: Not Entirely Accessible. School of Information Student Research Journal, 9(1). https://doi.org/10.31979/2575-2499.090103 Retrieved from https://scholarworks.sjsu.edu/ischoolsrj/vol9/iss1/3

This article is brought to you by the open access Journals at SJSU ScholarWorks. It has been accepted for inclusion in School of Information Student Research Journal by an authorized administrator of SJSU ScholarWorks. For more information, please contact scholarworks@sjsu.edu. 


\section{Digital Commons and CONTENTdm: Not Entirely Accessible}

\section{Keywords}

digital collections, digital commons, accessibility, technology, usability, contentdm

\section{Acknowledgements}

I would like to thank the Student Research Journal, its editors, and Dr. Anthony Bernier for this opportunity. 


\title{
Citation:
}

Walker, W., \& Keenan, T. (2015). Do you hear what I see? Assessing accessibility of digital commons and CONTENTdm. Journal of Electronic Resources Librarianship, 27, 69-87. doi:10.1080/1941126X.2015.1029395

\section{Reviewed by:}

Channon Arabit

Graduate Student

San Jose State University

Email: channontva@csu.fullerton.edu

\begin{abstract}
Objective: To explore the accessibility for visually impaired users in Digital Commons and CONTENTdm software.
\end{abstract}

Design: Unstructured interview of prearranged pages in each system.

Setting: The Maureen and Mike Mansfield Library and their instance of Digital Commons by Bepress and CONTENTdm by OCLC.

Subjects: A student that is visually impaired participated in the interview.

Methods: The authors interviewed a student using prearranged pages in Digital Commons and CONTENTdm system. The student examined home pages, browsing entities, papers, an overview of policies, and collections. More specifically, the pages ranged from ScholarWorks, the Student Research Experience, the Montana Memory Project, and the Boone and Crockett Club Records. In total, 20 pages were used in the interview; nine of those pages were based on the CONTENTdm software and 11 of the pages were from the Digital Commons platform. The authors did not prepare questions for the interview and allowed the student to "think-aloud" and provide feedback during the session (van Someren, Barnard, \& Sandberg, 1994). Also, the authors provided an introductory explanation of the interview and assistance when necessary.

Main Results: The student noted similar accessibility features in Digital Commons and CONTENTdm software, which include headings, descriptive links, and downloadable files. However, the student noted varying challenges in both systems that prohibited straightforward navigation. This includes inconsistent headings and the structure of the content. Comparing the two platforms, the student was not able to understand the content hosted on CONTENTdm, whereas Digital Commons had fewer problems with its accessibility. The authors indicate that the pages and structure of Digital Commons and CONTENTdm have varying accessibilities, which could hinder visually impaired users. 
Conclusion: While there have been advances in accessible technology, Digital Commons and CONTENTdm are not fully accessible. The authors noted that developing accessible digital collections is challenging, even with the World Wide Web Consortium (W3C) and its standards. Based on the results, the authors suggest that developers continue to address such issues and that additional participants are needed to assess accessibility with screen readers and its search functionality. Moreover, the authors suggested that other software could be analyzed for its accessibility, such as Luna Insight.

\section{Commentary}

As the Web and its content continues to grow, a large percentage of sites and databases have limited accessibility (J. N. Tatomir \& J. C. Tatomir, 2012; Hardesty, 2016). This includes the noted applications in this study; according to the platforms' sites, CONTENTdm allows institutions to showcase their online collections and "increase visibility through WorldCat," while Digital Commons hosts and publishes works from an institution, which includes faculty scholarship and student-run journals (OCLC, n.d.; Bepress, n.d.).

The methodology was thoroughly described, showing reliability. More specifically, the authors described the interview process, which included the "think-aloud" method, where the student provided feedback with little interference (van Someren, Barnard, \& Sandberg, 1994). This is similar to conducting usability tests and scenarios for websites or software (Schmidt \& Etches, 2012). Along with the methodology, the results detailed the positives and negatives of Digital Commons and CONTENTdm system. These findings are consistent with previous research, indicating a need for further research on digital collections and "best practices" for those with visual impairments (Southwell \& Slater, 2012, p. 469).

To improve the research, several participants are needed to evaluate the software for accessibility; although interviewing numerous participants could be time consuming, this would provide developers with data to continue creating accessibility features in these systems. Just like other studies indicated in the article, the authors primarily focused on visual impairments for their research. However, including interactions with other impairments are needed.

Accessibility, especially within the digital realm, relates to libraries and archives worldwide. In particular, the article connects to the information profession through its practices, which involve accommodating patrons and ensuring that resources are available. With this in mind, information professionals alike can advocate for accessibility features in systems Digital Commons and CONTENTdm. Furthermore, this research is a reminder to ensure that websites and software within libraries follow accessibility standards. 
The article emphasizes a need for accessibility within digital collections and its software. Overall, the authors have added to this field of research and are closer to closing the digital divide and ensuring that users have access to information electronically, which in return empowers users. 


\section{References}

Bepress. (n.d.). Digital commons. Retrieved from https://www.bepress.com/products/digital-commons/

Hardesty, E. (2016). Accessibility and special collections libraries: Using technology to close the digital divide. Public Services Quarterly, 12, 329333. doi:10.1080/15228959.2016.1222757

OCLC. (n.d.). CONTENTdm. Retrieved from https://www.oclc.org/en/contentdm.html

Schmidt, A., \& Etches, A. (2012). User experience (UX) design for libraries. Chicago, IL: ALA Editions.

Southwell, K., \& Slater, J. (2012). Accessibility of digital special collections using screen readers. Library Hi Tech, 30, 457-471. https://doi.org/10.1108/07378831211266609

Tatomir, J. N., \& Tatomir, J. C. (2012). Collection accessibility. Library Technology Reports, 48, 36-42. Retrieved from https://journals.ala.org/index.php/ltr/article/view/4689/5578

van Someren, M. W., Barnard, Y. F., \& Sandberg, J. (1994). The think aloud method: A practical guide to modelling cognitive processes. San Diego, CA: Academic Press. 